Family and Household Religion 



\section{Family and Household Religion}

Toward a Synthesis of Old Testament Studies, Archaeology, Epigraphy, and Cultural Studies

\section{Edited by}

RAINER Albertz, Beth ALPERT NAKHAI, SAUL M. OlyAN, and RÜDIGER SCHMITT

Winona Lake, Indiana

EISENBRAUNS

2014 
(C) Copyright 2014 Eisenbrauns

All rights reserved.

Printed in the United States of America.

www.eisenbrauns.com

\section{Library of Congress Cataloging-in-Publication Data}

Family and household religion : toward a synthesis of Old Testament studies, archaeology, epigraphy, and cultural studies / edited by Rainer Albertz, Beth Alpert Nakhai, Saul M. Olyan, and Ruediger Schmitt. pages $\mathrm{cm}$

Includes bibliographical references and indexes.

ISBN 978-1-57506-288-4 (hardback : alk. paper)

1. Families-Religious aspects-Judaism-To 70 A.D.-Congresses. 2. Jewish families-Conduct of life-History-To 70 A.D.—Congresses. 3. FamiliesPalestine-History-Congresses. 4. Families-Religious life-Congresses. 5. Palestine-Social life and customs-To 70 A.D.—Congresses. 6. Families-Biblical teaching—Congresses. 7. Sociology, Biblical—Congresses. 8. Bible. Old Testament-Criticism, interpretation, etc.-Congresses. I. Albertz, Rainer, 1943editor. II. Nakhai, Beth Alpert, 1951- editor. III. Olyan, Saul M., editor. IV. Schmitt, Ruediger, editor.

BS1199.F32F35 2014

$296.7^{\prime} 409014-\mathrm{dc} 23$

2014011290

The paper used in this publication meets the minimum requirements of the American National Standard for Information Sciences-Permanence of Paper for Printed Library Materials, ANSI Z39.48-1984. ${ }^{\mathrm{TM}}$ - 